\title{
The Impact of Training and Development on Workers' Productivity
}

\section{Halidu Salihu Gambo*}

Department of Political Science, Federal University Dutsinma, Nigeria

\begin{abstract}
Staff training and development is a key to achieving organizational success and corporate development. This study is aimed at finding out the Impact of Training and Development on workers' productivity via the TETFund Academic Staff Training and Development 2010 Sponsorship. Results revealed that training and development programmes improve employees' skills and performance at work place, enhance their technical knowhow/wherewithal to with stand the challenges of contemporary times, thus, an effective tool for sustaining and enhancing workers' productivity in the academia.
\end{abstract}

Keywords: Training and development skills; Higher productivity; Organizational development

\section{Introduction}

Achievement of objectives and good returns on investment could only be attained if human resources aspects of the human enterprise are properly developed through training and manpower development [1].

Atiomo, reiterated that an organization's future prosperity depends not only upon providing a product which is competitive neither in price, quality and quantity nor of simply increasing the range of products produced. If the organization has people of vision, energy and experience to direct the force and facilities, then the other requirement for success should follow.

An organization may have employees of ability and determination with appropriate equipment and managerial support yet productivity fails below expected standard. By and large, the missing factors in many cases are lack of adequate skills and knowledge which are acquired through manpower training and development.

Ojo as cited in Ngu [2] argues that despite the positive measure by Nigerian Government to encourage national indigenous manpower development is still not encouraging. In a similar line of reasoning studies by Yusuf, Jose and Ngu [3] also corroborated that most employing institutions in Nigeria tend to feel less concerned in training and development of its employees.

Ojo attributed this to financial inabilities and more generally lack of awareness of the importance of staff training and development programmes as they affect employees performance in their respective organizations.

In the light of the foregoing, any organization, no matter how advanced in science and technology cannot be represented by its building, plants and equipment; rather it is the achievement and development of human resource capital that is responsible for its increase in productivity [4].

It is against this backdrop, this study tends to look into the impact of training and development on workers' productivity through the Tertiary Education Trust Fund (TETFund) Academic Staff Training and Development of some selected universities in Nigeria.

\section{Methodology}

A sample of 10 universities in Nigeria was taken by using a university level data on staff training and development to find out its impact on workers' productivity. Though the definition of training in this study is on work related training and will be consistent to specification of these training variables. A retrospective design through indirect observation was adopted. Secondary data was collected from (TETFUND) academic staff training and development, 2010 sponsorship.

Frederick Taylor's Scientific Management Approach on Training and Development was adopted as a framework for the study

\section{Brief Literature and Theoretical Issues}

Ngu sees training and development to be the process of behavioural modification or moulding of workers to integrate organizational needs with their characteristics. Oribabor as cited in Kulkarni [5] added that training and development aims at developing competencies such as technical, human, conceptual and managerial for the furtherance of individual and organization growth.

In interpreting the above postulation Onah [6] maintains that at the time of technological change and innovation both new and old employees need to be trained to update their knowledge and skills and keep them abreast of the new development in the techniques and methods of doing their jobs in order to achieve individual and organizational objectives.

Halsay contents that training is the process of aiding employees in their present or future worth through the development of appropriate habit of thought and action, skills, knowledge and attitudes. Atiomo, in supporting the foregoing, opines that training is the process of acquiring knowledge, skills and attitude for the sole purpose of executing a specific or present job more effectively and efficiently.

Isyaku as cited in Kulkarni [5] corroborated that the process of training and development is a continuous one. It is an avenue to acquire more and new knowledge and develop further the skills and techniques to function effectively.

In reassessing and reviewing the submissions of Halsay, Cruden and Sherman, Ngu, Atiomo, Isyaku, Oribabor and Onah [6] as postulated above it shows that training is a course of action designed to enable

*Corresponding author: Halidu SG, Department of political science, Federal university dutsinma, Katsina state, Nigeria, Tel: +2347069161822; E-mail: shalidu@fudutsinma.edu.ng

Received May 22, 2015; Accepted July 28, 2015; Published July 30, 2015

Citation: Halidu SG (2015) The Impact of Training and Development on Workers Productivity. Review Pub Administration Manag 3: 160. doi:10.4172/23157844.1000160

Copyright: (c) 2015 Halidu SG. This is an open-access article distributed under the terms of the Creative Commons Attribution License, which permits unrestricted use, distribution, and reproduction in any medium, provided the original author and source are credited. 
the individual to realise his potential for self-growth and organizational development.

Flippo [7] as cited in Ngu conceptualises training as a calculated efforts aimed at increasing an employee skills for doing a particular job and developing person's knowledge for vocational purpose. In correlation with the above stipulations the wordings of French [8] can be reiterated, he maintains that training is a process that aims to bring up individuals up to a desire standards for present or potential assignment.

In a similar line of reasoning Glueck [9], sees training as a systematic process of altering the behaviour, knowledge and motivation of employees in a direction to increase organizational achievement. Glueck goes further to assert that training is a premeditated course of action taken in order to bring about changes in employees approach to work.

In his own way Stones [10] as cited in Atiomo [1] corroborated that training is any organizational planned efforts to change the behaviour of employees so that they can perform to an acceptable and standard result on the job.

In analysing the concept of training as submitted by Glueck, Stones, Flippo, and French above, it can be seen and understood that they examined training from both conceptual and operational viewpoints. Therefore, training helps employees to improve their work performance in order to ensure the standard and quality of work required by the organization to achieve both organizational and individuals predetermined objectives.

\section{Training objectives/needs}

According to Ngu training objectives can be derived from the current manpower situation. He reiterated that the existing manpower situation determines the training objectives both at the organizational and national level. Ngu corroborated that to be able to identify training needs, therefore will entail a comprehensive manpower survey which is usually an aspect of manpower planning. He added that a comprehensive manpower survey will expose the types of skills and personnel that need to be developed or trained.

Ngu reaffirms that for a country to enjoy both domestic and international influence and prestige, its citizens must be highly educated, honest and well respected rather than being ignorant, inefficient and corrupt. A training policy therefore is also geared towards that. Giangreco, Sebastiano, and Pecce as cited in Kulkarni [5] corroborated that the key determinants of overall satisfaction with training are perceived training efficiency and perceived usefulness of training.

Karthick as cited in Kulkarni affirms that training objectives tell the trainee that what is expected out of him at the end of the training programme. He added that training objectives are of great significance from a number of stakeholder perspectives; trainer, trainee, designer, evaluator

\section{The importance of manpower training and development}

George maintains that the importance of training is to help the employee acquire and maintain the necessary skills, capabilities and personal capacities to contribute more adequately to the attainment of organizational and rational objectives. In summary of the afore submission one may infer to say that the importance of training is to increase the present and future employees effectiveness, prepare them for advancement, retain them for greater versatility or for changes in organizational and national programmes. Tan, Hall and Boyce as cited in Kulkarni [5] observed that companies are making huge investment on training programmes to prepare them for future needs. Stavrou et al. posits that the main goal of training is to provide, obtain and improve the necessary skills in order to help organizations achieve their goals and create competitive advantage by adding value to their key resources.

\section{Types of training and development}

Induction training: Denny as cited in Ngu sees induction training as a programme of reception and introduction for new comers which begins on arrival and is designed to help them to settle into the new surroundings as quickly as possible. He summarizes the purpose of induction training as thus:

a) To give the history and background of the organization

b) To train the new comers on their job

c) To clearly define line of responsibility and line of authority

d) To fashion out organizational individual method

On the job and off the job training: Bass and Vaughan, Green and Biggs, and Flippo as cited in Ngu have identified two types of training via On the job and Off the Job.

On the Job Training according to these authorities implies to a technique of training through which an employee acquires relevant skills, knowledge and attitude at his actual work. According to Ojo; on the job training is where an employee is shown how to perform the job and allows doing it under supervision. Stones [10] redresses that during the on the job training the steps are repeated where an error is made until the employee learns the correct procedure. In the wording of Kulkarni [5]; on the job training may be seen as thus; job instruction, apprenticeship and coaching, job rotation, committee assignment, internship training, and training through step by step.

$\mathrm{Ngu}$, affirms that Off the Job training is a type that can be conducted outside the working environment. It is usually conducted in classrooms, in this case the trainee are given theoretical knowledge on how to handle a particular operation.

Kulkarni reaffirms and classifies off the job training as thus: Program instructions, class room lectures, work shop and seminars, conference method, vestibule training, behavioral modeling, experimental exercise, audio- visual method, case study method.

\section{Frederick winslow Taylor's approach}

The scientific selection and placement of worker on a scientifically designed job based on training together with the operation of reward and higher productivity became the cardinal doctrine in Taylor's scientific management approach [3].

Summary of submission

1. Development of science of work and determine scientifically a standard of operation through job design and job specification.

2. Scientific selection and progressive development of the workman.

3. Combination of science of work with the scientifically selected trained man. 
Citation: Halidu SG (2015) The Impact of Training and Development on Workers' Productivity. Review Pub Administration Manag 3: 160. doi:10.4172/23157844.1000160

Page 3 of 4

4. The continued cooperation between management and employees.

In the light of the foregoing, the organization without the human element is of no consequences. Therefore, the human element therein cannot be self-creative, self-initiative, self-innovative, self-fulfilling, self-growth and development without being empowered physically, mentally and intellectually through training and developmental programmes.
Gardner, Musner [11] and Hertzberg [12]; gave credence to the afore assertions and argue that an investment to enable workers acquire more knowledge may lead to more efficiency and higher productivity.

\section{Results and Discussion}

Table 1 shows 30 Ph.D. admissions, 15 Ph.D. bench work research, and 6 Master Degree admissions respectively. Out of the $30 \mathrm{Ph} . \mathrm{D}$. admissions in the year under review, all accomplished their programs

\begin{tabular}{|c|c|c|c|c|c|}
\hline 1 & Adamawa State University & Bello Y.I & Teknologi Malaysia & Ph.D Engr & 3 Years \\
\hline & & Pwaveno H.B & Putra, Malaysia & PhD Vet. Med & 3 years \\
\hline & & Musa I.A & Islamic Uni. Malaysia & PhD Industrial Chemistry & 3 years \\
\hline & & Danladi Ali & Ukraine Uni. & PhD Physics & 3 Years \\
\hline \multirow[t]{9}{*}{2} & Ahmadu Bello University & Abubakar S.S & East Anglia & PhD History & 3 Years \\
\hline & & Benedict MU & Bremen Germany & PhD Bench Work & 9 Months \\
\hline & & James Ali & Kansas USA & PhD Anatomy & 9 Months \\
\hline & & Abdulsamad A & Verginia USA & PhD Bench Work & 9 Months \\
\hline & & Yau Jamilu & Verginia & PhD Bench Work & 9 Months \\
\hline & & Magani M.G & BragaPortugal & PhD Bench Work & 9 Months \\
\hline & & Ahmed A. & Washington State University & PhD Bench Work & 9 Months \\
\hline & & Shide E.G & Kansas USA & PhD Bench Work & 9 Months \\
\hline & & Angela M. & Kansas & PhD Bench Work & 9 Months \\
\hline \multirow[t]{3}{*}{3} & Nnamdi Azikwe Uni & Abuchi C.S & Uni. Of London & PhD Med. Physics & 3 Years \\
\hline & & Chukwu A. & Nottingham UK & MSc Immunology & 1 Year \\
\hline & & Akunna G.I & Golsmith Univ. London & M.A Dance Therapy Research & 3 Months \\
\hline \multirow[t]{6}{*}{4} & Olabisi Onabanjo & Agbola AOJ & Nottingham UK & PhD Oncology & 3 Years \\
\hline & & Polarunsoho & Glyndwr Uni UK & PhD Comp Sci & 3 Years \\
\hline & & Bisuga N.A & Greenwich UK & PhD Bench Work & 6 Months \\
\hline & & Ajibola Abdul & Witwatersrand & PhD Physiology & 3 Years \\
\hline & & Agbatogun A & Edinburgh UK & PhD Education & 3 Years \\
\hline & & Taiwo B. & Aston Uni. & MSc Bio Tech & 2 years \\
\hline \multirow[t]{8}{*}{5} & Obafemo Awolowo University & Popoola M.O & Stelembosch S.A & PhD Bench Work & 9 months \\
\hline & & Awodiran M.O & Stelembosch S.A & PhD Bench Work & 6 months \\
\hline & & Sosan M.B & Cape Town & PhD Bench Work & 6 months \\
\hline & & Tijjani F. & Newcatle Uni UK & PhD Civil Engr & 3 years \\
\hline & & Aderogba M.A & Western Cape Town S.A & PhD Bench Work & 3 months \\
\hline & & Fisusi F.A & School of Pharm. London & PhD Pharm. & 3 years \\
\hline & & Eludiyan A.O & Uni. Exeter UK & M.Phil Geo & 1 year \\
\hline & & Daniyan M.O & Rhodes Uni. USA & PhD Biochem. & 3 years \\
\hline \multirow[t]{4}{*}{6} & University of Nigeria & Chigor V.N & Tswane Uni USA & PhD Micro Biology & 3 years \\
\hline & & Odimegwu D.C & Ruhr Univ. S.A & PhD Pharm & 3 years \\
\hline & & Asegbeloyin J.N & Adnan Univ Turkey & PhD Bench Work & 3 months \\
\hline & & Igbokwe C.O & Pretoria S.A & PhD Bench Work & 3 months \\
\hline \multirow[t]{2}{*}{7} & University of Port Harcourt & Ojapah M. & Brunel Uni. UK & Ph.D Eng. Design & 3 years \\
\hline & & Odia Amaze & Machester UK & MSc Eng. & 1 year \\
\hline \multirow[t]{3}{*}{8} & University of Ibadan & Omolara MO & WolverHampton & PhD Civil Eng. & 3 years \\
\hline & & Olaolrum FM & John Hokings USA & PhD Rep Health & 3 years \\
\hline & & Osifunke E & Queen Mary UK & LLM Juvenile Justice & 1 year \\
\hline \multirow[t]{6}{*}{9} & University of Maiduguri & Muhammed Yaji & UPM Malaysia & PhD Soil \& Water Eng. & 3 years \\
\hline & & Adamu G.S & Int Islamic Uni Malaysia & PhD LIS & 3 years \\
\hline & & Ibrahim A.O & UPM Malaysia & pHd Vet Med. & 3 years \\
\hline & & Aji I.S & UPM Malaysia & PhD Mech Eng & 3 years \\
\hline & & Abdulfatah A.A & Int Islamic Uni Malaysia & PhD Comp Sci & 3 years \\
\hline & & Hamman J.A & Upm Malaysia & PhD Public Management & 3 years \\
\hline \multirow[t]{5}{*}{10} & University of Jos & Bariy Katu & Bradford UK & M.A History & 1 year \\
\hline & & Ehalaiye 0.0 & Victoria Univ Newzealand & PhD Accounting & 3 years \\
\hline & & Goselle O.N & Wales UK & PhD Zoo & 3 years \\
\hline & & Audu I.D & Leeds UK & PhD Building & 3 years \\
\hline & & Momoh M.A & Western Cape Town S.A & PhD Geology & 3 years \\
\hline
\end{tabular}

Table 1: Showing the TET FUND academic staff training and development. 
and have been elevated/promoted/upgraded in their various academic and professional endeavors. Records from TETFUND have shown that as at the material time of their take off their positions were ranging from Assistant Lecturer to Lecturer 1 respectively [13].

\section{Empirical review}

Dearden, Reed and Van Reenen [14] used a new panel of British industries and variety of estimation techniques to investigate and interrogate "The Impact of Training on Productivity and Wages" and revealed that work related training is associated with significantly higher productivity. Thus, a $1 \%$ point increase in training is associated in value added per hour of about $0.6 \%$ and an increase in hourly wages of about $0.3 \%$.

Studies by Konings and Vanormelingen [15] empirically investigated the impact of firm provided training on both wages and productivity, by using a firm level data set of more than 170,000 firms active in Belgium and revealed that training boosts marginal productivity of an employee more than it increases its wage [16]. Thus, productivity premium for a trained employee is on average around $23 \%$ while the wage premium is only $12 \%$.

Studies by Abdul Ghafoor, Furqan, and Muhammed [17] confirmed that job training, training design and delivery style have significant effect on organizational performance. Thus, it means that training increases the overall organizational productivity.

Literature findings by Kulkarni [5] also confirmed that training and development programmes improve employee's performance at work place, it updates employee's knowledge and enhances their personal skills and as well helps in avoiding managerial obsolescence.

Studies by TET Fund revealed that to realise Nigeria's national vision of becoming one of the top 20 economies in the world by 2020AD, Nigeria must produce world class manpower, possible only through world class tertiary institutions equipped not only with the requisite physical infrastructure and structural facilities but, above all, world class lecturers to impart current and in-depth knowledge, conduct research, publish the outcomes and produce personnel that is nationally competent and globally competitive. Thus, this is only achievable through manpower training and development.

This study is also in tandem with Kulkarni, Abdul Gafoor K et al. and TET Fund and thus, reliably concludes that there is a symbiotic relationship between training/development and employees higher productivity.

\section{Policy implication}

Tertiary Education Trust Fund should improve on its training policy in its entire ramification because in recent times academics are being faced with innovations and techno- scientific developments so as to meet up with the changing trends and circumstances [18]. Desirous is the need to increase the ratio of admissions for those in the Arts, Humanities and Social Sciences as records have shown that out of the $45 \mathrm{PhD}$ admission of the ten universities, only three came from arts and social sciences which is about $6 \%$ of the total admission.

\section{Conclusion}

This study has underscored the impact of training and development on workers' productivity. Findings from this research uncovered that academic staff training and development is an effective tool for employee's higher productivity in the academia. Hence, academic staff can only work effectively if given the right training required for such task.
This study is in consistent with the findings of Dearden, Reed and Van Reenen [14] which revealed that work related training has a symbiotic relationship with higher productivity. This position was also reiterated in the findings of Konings and Vanormelingen [15] and corroborated that work related training is associated with significantly employee's higher productivity.

Kulkarni, Abdul Gafoor K. et al. also corroborated the above findings evidenced from the Indian, Pakistani and Bangladesh's examples that job training has significant effect on organizational performance. Thus, in the light of the foregoing, this study reliably concludes that academic staff training has a positive impact on workers' productivity in the academia. Academics' will discharge their designated responsibilities effective if the academic system/environment fosters academic fellowships, workshops, seminars and conferences. This conclusion is also in tandem with early studies such as Argyris [19,20], Musner [11], Hertzberg [12] Bass and Vaughan, French, Drucker [21], Flippo, Glueck [9] and Stones, Ngu and Atiomo [1].

\section{References}

1. Atiomo AC (2000) Practical Human Resources Management. Lagos, Nigeria.

2. Ngu SM (2006) Management Principles and Workers Motivation in Nigeria. Gaskiya Corporation Ltd., Zaria, Nigeria.

3. Ngu SM (1994) Personnel Management in Nigeria, Principles and Practice Gaskiya Corporation Ltd., Zaria, Nigeria.

4. Black SE, Lynch LM (1996) Human-Capital Investments and Productivity. The American Economic Review 86: 263-267.

5. Kulkarni PP (2013) A Literature Review on Training \& Development and Quality of Work Life. Journal of Arts, Science and Commerce 4:136-143.

6. Onah FO (2003) Human Resources Management: Theory and Practice Organizational Performance Global Journals Inc., Lagos Nigeria.

7. Flippo E (1980) Principles of Personnel Management (5thed) Mac Graw Hill, UK.

8. French W (1974) Objectives of Training and Development. The American Management Association Inc., USA.

9. Glueck WF (1986) Personnel: A Diagonostic Approach. Business Publication Inc., Texas.

10. Stones TH (1982) Understanding Personnel Management. The Dryden Press New York

11. Musner B, Syneyderman B (1959) The Motivation to Work. John Wiley, New York

12. Hertzberg FV (1966) Work and the Nature of Man. World Publishing, New York.

13. Akpan NC (1982) Public Administration in Nigeria. Longman Plc, Lagos, Nigeria.

14. Dearden L, Reed H, Reenan JV (2006) The Impact of Training on Productivity and Wages: Evidence from British Panel Data. Oxford Bulletin of Economics and Statistics 68: 397-421.

15. Konings J, Vanormelingen S (2010) The Impact of Training on Productivity and Wages: Firm Level Evidence. IZA Discussion Paper, Discussion paper series, Bonn.

16. Acemoglu D, Pischke JS (1998) Why Do Firms Train? Theory and Evidence. Quarterly Journal of Economics 113: 79-119.

17. Raja AGK, Furqan AK, Muhammad AK (2011) Impact of Training and Development on on Organizational Performance. Global Journal of Management and Business Research 11: 63-68.

18. Blundell R, Dearden L, Meghir C, Sianesi B (1999) Human capital investment: The returns from education and training to the individual the firm and the economy. Fiscal Studies 20: 1-23.

19. Argyris C (1957) Personality and Organization: the Conflict between System and the Individual. Administrative Science Quarterly 3: 134-137.

20. Argyris C (1964) Integrating the Individual and the Organization. Wiley, New York

21. Drucker PF (1974) Management. Heinemann Publishing Ltd., London. 